\title{
Differential expression of mesotocin receptors in the uterus and ovary of the pregnant tammar wallaby
}

\author{
Andrew L Siebel ${ }^{1,2}$, Ross A D Bathgate ${ }^{2}$ and Laura J Parry ${ }^{1}$ \\ ${ }^{1}$ Department of Zoology and ${ }^{2}$ Howard Florey Institute, University of Melbourne, Parkville, Victoria, 3010, Australia \\ Correspondence should be addressed to A Siebel; Email: asiebel@unimelb.edu.au
}

\begin{abstract}
Mesotocin, an oxytocin-like peptide, is released in highest concentrations during parturition in macropodid marsupials. In late pregnant wallabies, uterine sensitivity to mesotocin increases markedly in the myometrium of the gravid uterus. This coincides with a significant increase in myometrial mesotocin receptor concentrations 3-4 days before term. To date, there is no information on mesotocin receptor gene expression in female wallaby reproductive tissues. This study aimed to examine mesotocin receptor gene expression in the uterus and ovaries of pregnant tammar wallabies, and to localise mesotocin receptors within the uterus. An RT-PCR strategy produced a consensus nucleotide sequence of $834 \mathrm{bp}$, which encoded 278 amino acids of transmembrane domains I to VI. This protein sequence has approximately $80 \%$ homology with the bovine and rat oxytocin receptor exon 2 region. Only one mesotocin receptor was detected in the tammar genome. The myometrium and mammary gland both expressed a $4.1 \mathrm{~kb}$ mesotocin receptor gene transcript. Myometrial mesotocin receptor gene expression increased on day 22 of the 26-day gestation and was significantly higher in the gravid than the non-gravid uterus in late pregnancy. This pattern of mesotocin receptor gene expression paralleled mesotocin receptor concentrations. Mesotocin binding sites were localised only to the myometrium, the highest densities being observed in the gravid uterus. Finally, this study showed high expression of mesotocin receptors in the corpus luteum. The pattern of luteal mesotocin receptor expression differed from the myometrium, with a decrease in mesotocin receptors occurring on the day of expected births.
\end{abstract}

Reproduction (2005) 129 639-649

\section{Introduction}

The oxytocin (OT) receptor belongs to the class 1 G-protein-coupled, seven-transmembrane domain receptor superfamily and primarily signals via $\mathrm{G} \alpha \mathrm{q}$ proteins through the phospholipase C-beta isoform (PLC- $\beta$ ). Kimura et al. (1992) first isolated and identified a cDNA encoding the human OT receptor. To date, the OT receptor-encoding sequences have been identified in the pig (Gorbulev et al. 1993), rat (Rozen et al. 1995), sheep (Riley et al. 1995), cow (Bathgate et al. 1995), mouse (Kubota et al. 1996) and rhesus monkey (Salvatore et al. 1998). Unlike eutherians, which secrete OT, marsupials secrete mesotocin (MT), which differs from OT by one amino acid, an isoleucine for leucine at position 8 . The presence of OT-like receptors in marsupials was first demonstrated in the brushtail possum uterus, mammary gland and median vaginal sacs (Sernia et al. 1990, 1991). These studies reported that the OTbinding site was not specific for MT over OT, vasotocin (AVT) or arginine vasopressin (AVP). This work was supported by data from two separate studies which demonstrated a single OT-binding site in uterine tissues of the pregnant tammar wallaby, using either ${ }^{125}$ I-oxytocin receptor antagonist (OTA; Parry et al. 1997) or ${ }^{3} \mathrm{H}-\mathrm{OT}$ (Sebastian et al. 1998). This OT-binding site bound MT and OT with similar high affinities, whereas AVP, lysine [Lys-8]vasopressin (LVP) and $\left[\mathrm{Phe}^{2}\right]$-vasopressin (PP) had much lower binding affinities. This is consistent with binding to an OT-like receptor, and not an AVP receptor.

The tammar wallaby (Macropus eugenii) is a well-established model to differentiate between the role of maternal systemic and fetal-specific factors in the regulation of uterine MT receptors during pregnancy. Female tammar wallabies give birth to small, altricial young after a short gestation period of only 26 days after reactivation of the diapausing blastocyst (Renfree et al. 1996). They have two anatomically separate uteri, which open into the anterior vaginal expansion via separate cervices (Tyndale-Biscoe \& Renfree 1987). Due to the unique reproductive tract anatomy of marsupials, the influence of the conceptus on the regulation of myometrial MT receptors can be isolated from maternal factors, with direct comparison between the gravid and non-gravid uterus. From day 23 of gestation, MT receptor concentrations in the myometrium of the gravid uterus increase markedly, whereas in the 
non-gravid myometrium they remain unchanged (Parry et al. 1997). In fact, MT receptors are significantly decreased in the non-gravid myometrium on the last 2 days of gestation. The changes in MT receptor density in the gravid uterus are matched by large increases in uterine sensitivity to exogenous MT (Parry et al. 1997). A recent study in unmated tammars showed no increase in MT receptors in either uterus despite the similar lengths of the luteal phase in non-pregnant and pregnant tammars (Siebel et al. 2002a). These data confirm that the increase in MT receptors is not only unique to the gravid uterus, but also pregnancy specific.

To date, there is no information on MT receptor gene expression in relation to MT receptor concentrations during pregnancy in female wallaby reproductive tissues. Moreover, MT receptors have not been localised within the wallaby uterus. Earlier work in the tammar prostate gland elucidated a partial sequence of the tammar MT receptor gene, which encoded a protein of 196 amino acids (Parry \& Bathgate 1998). The derived amino-acid sequence had relatively high homology $(74-77 \%)$ with the region extending from putative transmembrane domains II to $\mathrm{VI}$ in all eutherian OT receptors and relatively low homology (38-52\%) with AVP receptors. Although MT receptor gene transcripts were demonstrated in the prostate gland (Parry \& Bathgate 1998), this study did not include female reproductive tissues. Therefore, the overall aim of this study was to examine myometrial MT receptor gene expression in the reproductive tract and ovaries of the pregnant tammar wallaby. This study also included autoradiography to localise MT receptors within the uterus.

\section{Materials and Methods}

All animal experiments were conducted with approval from the La Trobe University Animal Ethics Committee (no. AEC 00/3 L) and the Department of Natural Resources and Environment (permit no. 10002261).

\section{Animals}

Female tammar wallaby (M. eugenii) tissues were collected on Kangaroo Island (SA, Australia) from wild-shot animals with approval from the South Australian Department for Environment and Heritage (permit no. Q24436) and the Victorian Department of Natural Resources and Environment (permit no.10000449). Females were housed with males in open, grassed enclosures at the Wildlife Reserve (La Trobe University, Bundoora, VIC, Australia) with water and kangaroo pellets readily available.

A pilot study demonstrated no significant differences in either MT receptor mRNA or receptor concentrations between wild-shot and colony animals at the same stage of gestation. Therefore, data from wild and colony-housed pregnant tammars were pooled at each stage of gestation. Gestational age was estimated from fetal crown rump length and head-length measurements, and verified by specific developmental characteristics validated from a large sample size (>300 animals) obtained from timemated animals in a breeding colony (L J Parry, unpublished observation). In all cases, these measurements are accurate to within half a day. To examine MT receptor mRNA expression in a range of tissues at a specific stage of gestation (day 23), pregnancies were synchronised in a group of colony-housed adult wallabies by removing the pouch young (RPY) from females assumed to be carrying a blastocyst in embryonic diapause.

\section{Tissue collection}

All tissues used for RNA analysis were collected as quickly as possible after the animal had stopped breathing. Colony-derived animals were killed by an overdose injection $(3-5 \mathrm{ml})$ of pentobarbitone sodium (Lethabarb; Virbac Australia Pty Ltd, Parkhurst, NSW, Australia) $(325 \mathrm{mg} / \mathrm{ml})$ into the heart. The nipples and mammary glands were collected before the reproductive tract was removed via laparotomy. The ovaries and oviducts were removed, and the two uteri dissected from the extrauterine tissue and cut longitudinally to open the uterine cavity. The fetus, placenta, cervix and median vagina were all collected, as was the endometrium when separated from the myometrium. All tissues were placed in liquid nitrogen and stored at $-80^{\circ} \mathrm{C}$ until further processing. The gravid and non-gravid uteri were collected from day-23 pregnant females and cut in transverse section so that autoradiography binding studies could be performed on the intact myometrium, endometrium and placenta (gravid uterus only). These tissues were fixed in Tissue-Tek O.C.T. embedding medium (ProSciTech, Thuringowa, QLD, Australia) and frozen at $-80^{\circ} \mathrm{C}$. Serial sections $(8-10 \mu \mathrm{m})$ were cut with a cryostat at $-20^{\circ} \mathrm{C}$ and thaw mounted on gelatin-coated slides. Sections were then stored at $4{ }^{\circ} \mathrm{C}$ overnight in the presence of silica gel.

\section{Mesotocin (MT) receptor gene}

The nucleotide and derived amino-acid sequence of the $5^{\prime}$-coding region of the tammar MT receptor were obtained with the First-Choice RLM-RACE kit (Ambion, Geneworks, Adelaide, Australia), according to the manufacturer's instructions. Total RNA was extracted from the gravid myometrium (day 23), using $2 \mathrm{ml}$ RNAWiz (Ambion) per $100 \mathrm{mg}$ tissue. After isopropanol precipitation, the RNA pellet was resuspended in $\mathrm{H}_{2} \mathrm{O}$ treated with RNA Secure (Ambion). First-strand cDNA was synthesised from $5 \mu \mathrm{g}$ total RNA, using $0.5 \mu \mathrm{g} / \mu \mathrm{l}$ random hexamers or a tammar MT receptor-specific primer (MTR 490, 5'-CCT CAT CTG TTA CCT GTG AGG-3'; Geneworks) and $100 \mathrm{U}$ Superscript II RNase $\mathrm{H}^{-}$reverse transcriptase (Invitrogen, Mulgrave, Australia) in a total volume of $20 \mu \mathrm{l}$. A volume of $2 \mu \mathrm{l}$ of the cDNA was used as a template for the PCR reaction to amplify the $5^{\prime}$-end of the MT receptor transcript, with two nested tammar MT 
receptor-specific primers (MTR 5'F1, 5'-GGC ACT TCT AGT AGT CTA AGC- $3^{\prime}$ and MTR 5'R5, 5'-CAG ATC TAG TGG TGG CTG TGT- $3^{\prime}$ ). The PCR conditions were as follows: 40 cycles of 1 -min denaturation at $95^{\circ} \mathrm{C}, 1 \mathrm{~min}$ at the annealing temperature of $55^{\circ} \mathrm{C}$ and a 2-min extension at $72^{\circ} \mathrm{C}$. A further 15 -min extension step was added at $72{ }^{\circ} \mathrm{C}$. This yielded a DNA product of approximately $350 \mathrm{bp}$, which was eluted, ligated into the pGEM-T vector (Promega), transformed into JM109 competent cells and sequenced as described previously (Parry et al. 1997).

\section{Southern blot analysis of genomic DNA}

Genomic DNA $(15 \mu \mathrm{g})$ extracted from male liver tissue was digested with a single restriction enzyme (HindlII) and electrophoresed on a $0.5 \%$ agarose gel in $0.5 \times \mathrm{TBE}$. After depurination in $0.2 \mathrm{M} \mathrm{HCl}$, alkali denaturation and neutralisation, DNA was capillary transferred to nylon membranes (Hybond $\mathrm{N}+$; Amersham Life Sciences, Castle Hill, Australia) in $20 \times$ saline-sodium citrate (SSC) and UV cross-linked. Membranes were prehybridised for $3 \mathrm{~h}$ at $65{ }^{\circ} \mathrm{C}$ in a solution containing $0.25 \mathrm{M} \mathrm{NaHPO}_{4}(\mathrm{pH} 7.2)$, $1 \mathrm{mM}$ EDTA, 20\% (w/v) sodium dodecyl sulfate (SDS) and $0.5 \%(\mathrm{w} / \mathrm{v})$ blocking reagent (Roche), and hybridised overnight at $65^{\circ} \mathrm{C}$ with a $580 \mathrm{bp}$ tammar MT receptor cDNA probe labelled with digoxygenin $(0.35 \mathrm{mM}$; Roche $)$ by PCR, according to the manufacturer's instructions. After hybridisation, membranes were washed three times in $0.2 \mathrm{M} \mathrm{NaHPO}_{4}, 1 \mathrm{mM}$ EDTA and $1 \%(\mathrm{w} / \mathrm{v}) \mathrm{SDS}$ at $62^{\circ} \mathrm{C}$. Hybridisation signals were subsequently detected by chemiluminescence with CPSD (disodium 3-(4-methoxy spiro\{1,2-dioxetane-3, $2^{\prime}$-(5'-chloro) tricyclo[3.3.1.1. $\left.1^{3,7}\right]$ decan\}-4-yl) phenyl phosphate) as substrate. Membranes were subsequently exposed to film at $-80^{\circ} \mathrm{C}$ for $48 \mathrm{~h}$.

\section{Northern hybridisation}

Total RNA was extracted from myometrial samples obtained on days 17, 23 and 25 of gestation, and also from mammary gland tissue on days $4-5$ post-partum and liver on day 23 of gestation to use as positive and negative controls respectively. Approximately $20 \mu \mathrm{g}$ total RNA was denatured in $20 \times 3$-morpholino-propanesulfonic acid (MOPS), $50 \%(\mathrm{w} / \mathrm{v})$ formamide (Asia Pacific Specialty Chemicals, Seven Hills, Australia) and $2.2 \mathrm{M}$ formaldehyde (Asia Pacific Specialty Chemicals) for $15 \mathrm{~min}$ at $65^{\circ} \mathrm{C}$. Samples were then subjected to electrophoresis on a $1.3 \%(\mathrm{w} / \mathrm{v})$ agarose $/ 2.2 \mathrm{M}$ formaldehyde/ $1 \times$ MOPS gel and transferred to an optimised Hybond-NX membrane (Amersham Life Sciences) by overnight capillary transfer. Samples were then covalently attached to the membrane by UV cross-linking at $65^{\circ} \mathrm{C}$ for $2 \mathrm{~h}$. An RNA ladder $(0.249 .5 \mathrm{~kb})$ (Promega) was included on the gel as a molecular size marker. Specific MT receptor transcripts were identified with a $480 \mathrm{bp}$ tammar MT receptor cDNA probe, derived by PCR and labelled with $\left[\alpha-{ }^{32} \mathrm{P}\right] \mathrm{dCTP}$ to a specific activity of $6.4 \times 10^{8}$ c.p.m./mg DNA by random primer extension. The membranes were prehybridised in buffer $(0.25 \mathrm{M}$ sodium phosphate, $1 \mathrm{mM}$ EDTA and SSC: $0.3 \mathrm{M}$ sodium citrate and $3 \mathrm{M} \mathrm{NaCl}, \mathrm{pH} 7.0$ ) at $65^{\circ} \mathrm{C}$ for

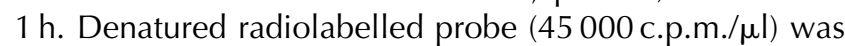
then added to fresh buffer and incubated at $65^{\circ} \mathrm{C}$ overnight. After hybridisation, membranes were washed twice in $2 \times \mathrm{SSC} / 0.1 \%(\mathrm{w} / \mathrm{v})$ SDS at room temperature for $10 \mathrm{~min}$. The final wash used $0.2 \times \mathrm{SSC} / 0.1 \%(\mathrm{w} / \mathrm{v})$ SDS at $65^{\circ} \mathrm{C}$ for $30 \mathrm{~min}$. Membranes were then exposed to film (BIOMAX MS $-{ }^{32} \mathrm{P}$; Kodak Australia), with a single intensifying screen at $-80^{\circ} \mathrm{C}$ for $48 \mathrm{~h}$.

\section{Quantitative (Q-)PCR analysis}

For each sample, $600 \mathrm{ng}$ total RNA was reverse transcribed in a $30 \mu$ l reaction containing $1 \times$ TaqMan buffer, $5.5 \mathrm{mM}$ $\mathrm{MgCl}_{2}, 500 \mu \mathrm{m}$ dNTPs, $2.5 \mu \mathrm{M}$ oligo d(T), $0.4 \mu \mathrm{l}$ RNAse inhibitor and $1.25 \mathrm{U} / \mu \mathrm{l}$ MultiScribe reverse transcriptase (Applied Biosystems, Scoresby, VIC, Australia). A second reaction mix using $30 \mathrm{ng}$ total RNA from each sample and a series of myometrium RNA dilutions (100-0.001 ng) was prepared for the endogenous reference $18 \mathrm{~S}$ ribosomal RNA PCR reactions and to generate the $18 \mathrm{~S}$ standard curves respectively. First-strand cDNA synthesis for all samples was carried out simultaneously at $25^{\circ} \mathrm{C}$ for $10 \mathrm{~min}, 42^{\circ} \mathrm{C}$ for $45 \mathrm{~min}$ and $95^{\circ} \mathrm{C}$ for $10 \mathrm{~min}$ with a final cooling temperature at $4{ }^{\circ} \mathrm{C}$, before storage at $-20^{\circ} \mathrm{C}$. The $18 \mathrm{~S}$ and tammar-specific MT receptor primers and FAM (6-carboxy fluorescein)-labelled probes were designed with Primer Express (Applied Biosystems) and provided by Keystone Division (Biosource International, Foster City, CA, USA), as described by Siebel et al. (2002b). All reactions were carried out in triplicate $25 \mu \mathrm{l}$ volumes consisting of $1 \times$ TaqMan Universal PCR Master Mix, $0.8 \mu \mathrm{M}$ forward and $0.8 \mu \mathrm{M}$ reverse MT receptor primers, $0.4 \mu \mathrm{M}$ MT receptor probe and $2.5 \mu \mathrm{l}$ cDNA template. Each plate included a sample in triplicate with water to replace the cDNA template (NTC) and a series of $18 \mathrm{~S}$ standards with known RNA concentrations. The relative $C_{T}$ standard curve method was used in this study; therefore, MT receptor and $18 \mathrm{~S}$ gene expression was assessed in separate PCR reactions with $C_{T}$ values for both genes related to those of the $18 \mathrm{~S}$ standards. The amount of MT receptor mRNA expressed in each sample was calculated from regression lines generated from the standard curves and presented as MTR/18S mRNA (Siebel et al. 2002b).

\section{Radioreceptor assay}

Radioreceptor assays were carried out as described by Siebel et al. $(2002 b)$, using the labelled ligand $\left[{ }^{125} \mathrm{l}\right]$ $\mathrm{d}\left(\mathrm{CH}_{2}\right)_{5}\left[\mathrm{Tyr}(\mathrm{Me})^{2}, \mathrm{Tyr}^{4}, \mathrm{Orn}^{8}\right.$, Tyr- $\left.\mathrm{NH}_{2}^{9}\right]$-vasotocin $\left({ }^{125} \mathrm{I}\right.$ OTA; ProSearch International Australia Pty Ltd, Malvern, VIC, Australia) with a specific activity of $2200 \mathrm{Ci} / \mathrm{mmol}$. The receptor assay mixture consisted of duplicate aliquots of $100 \mu \mathrm{l}$ diluted tissue suspension, $100 \mu \mathrm{l}{ }^{125}$ I-OTA (15000-20000 c.p.m./tube) and $100 \mu \mathrm{l}$ assay buffer (50 $\mathrm{mM}$ Tris- $-\mathrm{HCl}, 5 \mathrm{mM} \mathrm{MgCl} 2$ and $0.2 \%$ bovine serum 
albumin (BSA), pH 7.6) containing a range of $0.01-$ $1 \mathrm{pmol} /$ tube unlabelled OTA standards. Protein concentrations in the membrane fractions were measured with a DC Protein Assay Kit (Bio-Rad) with BSA as the protein standard. Protein concentrations were $60-120 \mu \mathrm{g} / \mathrm{ml}$, which is within the range where specific binding is linearly correlated with protein concentration. Data were analysed by non-linear regression, using the Ligand computer program (Munson \& Rodbard 1980), to obtain the binding affinity $\left(K_{\mathrm{a}}\right)$ and the receptor content $\left(R_{\mathrm{O}}\right)$ for radiolabelled ligand binding.

\section{Competitive binding studies}

Competitive binding assays determined the ligand specificity of the ${ }^{125}$ I-OTA binding site in the ovary. A $100 \mu \mathrm{l}$ aliquot of membrane preparation obtained from pooled corpora lutea collected on day 25 of gestation was incubated with $100 \mu \mathrm{l}^{125} \mathrm{I}$-OTA in competition with a series of ligand solutions of varying molar concentrations prepared in assay buffer. A $100 \mu \mathrm{l}$ aliquot of the following ligands was used: OT $(0.1,0.5,1,5,10$ and $100 \mathrm{pmol} /$ tube), MT (0.1, $0.5,1,5,10$ and $100 \mathrm{pmol} /$ tube), AVT $(0.1,0.5,1,5,10$ and $100 \mathrm{pmol} /$ tube), $\operatorname{LVP}(1,5,10,50,100$ and $500 \mathrm{pmol} /$ tube $)$ and PP (10, 50, 100, 500, 1000 and 2000 pmol/tube) (all from Sigma Pharmaceuticals), as well as OTA (0, 0.01, 0.02, $0.1,0.2,1$ and $100 \mathrm{pmol} /$ tube) (kindly provided by Dr Maurice Manning). The interaction of each peptide with ${ }^{125}$ I-OTA was expressed as a relative displacement curve $\left(B / B_{0}\right)$ versus log molar concentration and fitted with sigmoidal curves (GraphPad Prism, San Diego, CA, USA). Two independent experiments were conducted with duplicates of each ligand to determine the respective $\mathrm{IC}_{50}$ values.

\section{Localisation of MT binding sites}

Tissue sections were first brought to room temperature before incubation for $30 \mathrm{~min}$ in washing buffer $(50 \mathrm{mM}$ Tris- $\mathrm{HCl}(\mathrm{pH} 7.4))$. Immediately after washing, sections were incubated with $100 \mu \mathrm{l}^{125} \mathrm{I}-\mathrm{OTA}$ (50-100 000 c.p.m.) in incubation buffer $(50 \mathrm{mM}$ Tris- $\mathrm{HCl}, 5 \mathrm{mM} \mathrm{MgCl} 2$ and $0.1 \%$ BSA) for $1 \mathrm{~h}$ at room temperature. Non-specific binding was determined by the addition of $2 \mu \mathrm{M}$ unlabelled OTA peptide under the same conditions as for ${ }^{125}$ I-OTA binding. The incubation step was terminated by washing sections in ice-cold washing buffer. Sections were then air-dried and placed in the Fujix BAS IP magazine holder 2040 TR (Fujifilm, Mulgrave, VIC, Australia) apposed to a phosphoimager plate for $24 \mathrm{~h}$. This was visualised with Analytical Imaging Station software on the Bio-imaging analyser (Fujix BAS 2000). For a clearer image, the sections were exposed to a film sensitive to ${ }^{125}$ I-radioactivity (MS film: Amersham Life Science) for $24-48 \mathrm{~h}$ at $-80^{\circ} \mathrm{C}$. The film was developed in an AGFA CP 1000 developer (AGFA-Gavaert Ltd, Nunawading, Australia) for localisation of the radioactivity. For a direct comparison between radiolabelling and tissue histology, serial sections were briefly fixed in $4 \%$ paraformaldehyde
(PFA) and stained with haematoxylin and eosin by wellestablished procedures.

\section{Statistical analysis}

Data for both MT receptor mRNA and receptor concentrations did not show homogeneity of variance and were therefore log-transformed. To test for significant differences between stages, one-way ANOVA was used with a least squares difference post-hoc test (SPSS, Inc., Chicago, IL, USA) at the 95\% confidence interval. Paired $t$-tests were performed on the log-transformed data to test for significant differences between the gravid and non-gravid uteri. All data are reported as mean \pm S.E.M.

\section{Results \\ MT receptor gene}

Sequencing analysis of the various PCR fragments obtained with 5'RACE with tammar MT receptor-specific primers produced a consensus nucleotide sequence of $834 \mathrm{bp}$ (GenBank accession no. AY206419), which encodes a protein of 278 amino acids. This sequence accounts for the equivalent of the bovine/rat OT receptor exon 2, or mouse/human OT receptor exon 3 region. There was $100 \%$ sequence homology compared with the previous tammar MT receptor nucleotide sequence reported by Parry and Bathgate (1998). An additional 180 nucleotides were identified at the $5^{\prime}$-end, which starts approximately 33 amino acid residues into the amino-terminus. This sequence does not include the methionine start site, but comprises the first six transmembrane domains. 3'-RACE was attempted but was unsuccessful probably due to the large $3^{\prime}-U T R$ of the MT receptor, as predicted from the size of the transcript in the Northern blot.

The derived 278-amino-acid sequence of the putative tammar MT receptor exon 2 region has approximately $80 \%$ homology compared with the human (Kimura et al. 1992), ovine (Riley et al. 1995) and bovine (Bathgate et al. 1995) OT receptor sequences. Highest similarity (96\%) is seen in the transmembrane domains II and III and extracellular loop 1 (Fig. 1). In contrast, there is only $82 \%$ homology in the region containing the amino-terminus, the first transmembrane domain and the intracellular loop. The wallaby MT receptor also shows $72 \%$ and $78 \%$ homology to human vasopressin receptors, $\mathrm{V} 1 \mathrm{~A}$ and $\mathrm{V} 1 \mathrm{~B}$ respectively, but there is no significant similarity between the tammar MT receptor and the only complete vasotocin receptor sequence, that of the bullfrog (Rana catesbeiana).

Hybridisation of HindIII-digested genomic DNA with a tammar MT receptor-specific probe indicated a specific band at approximately $4.1 \mathrm{~kb}$ (Fig. 2), demonstrating a single MT receptor gene in the wallaby genome.

\section{MT receptor gene expression}

Initial RT-PCR analysis revealed a single PCR product strongly expressed in the myometrium, corpus luteum, 


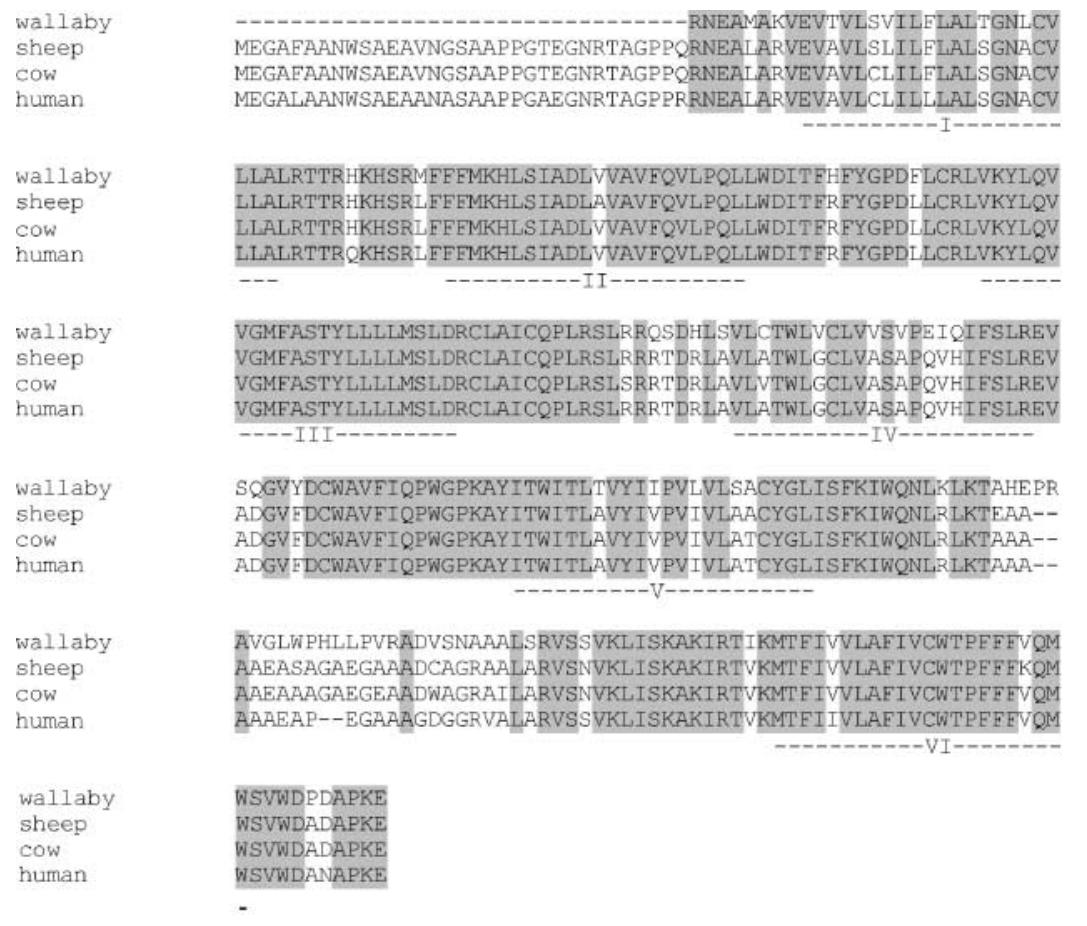

Figure 1 CLUSTAL W (1.82) multiple sequence alignment of the tammar wallabyMT receptor exon 2 amino-acid sequence with the sheep (no. AAK28287), cow (no. NP_776559) and human (no. NP_000907) OT receptor amino-acid sequences. Amino acids common to all species are highlighted in grey. Predicted locations of putative transmembrane domains $(\mathrm{I}-\mathrm{VI})$ are indicated below the amino-acid sequence (dashed line). cerebellum and hypothalamus of the brain. MT receptor gene transcripts were also weakly expressed in the heart, follicle and oviduct (data not shown). Northern hybridisation of total RNA demonstrated the presence of a MT receptor transcript in both gravid and non-gravid myometrium across a range of pregnancy stages and in the mammary gland (Fig. 3). The size of the transcript was approximately $4.1 \mathrm{~kb}$, estimated from the size of the $28 \mathrm{~S}$ $(4.7 \mathrm{~kb})$ and $18 \mathrm{~S}(1.9 \mathrm{~kb})$ ribosomal RNA bands and an RNA marker. Maximal expression was observed in the gravid myometrium during late pregnancy (Fig. 3, lanes 3 and 5), with a distinctive decrease in MT receptor transcript expression in the non-gravid myometrium (lanes 4 and 6). The signal intensity of the MT receptor transcript in the mammary gland (lane 7) from early lactation was relatively low and equivalent to that observed in nongravid myometrium from day 23 of pregnancy. No MT receptor transcript was detected in the liver (lane 8), which was used as a negative control.

A comparison of MT receptor gene expression between different tissues by Q-PCR revealed that MT receptor mRNA levels were significantly higher in the gravid myometrium than the non-gravid myometrium (paired $t$-test, $P=0.017)$, placenta $(P=0.023)$, gravid endometrium $(P=0.011)$ and median vagina $(P=0.007)$ (Fig. 4). However, the highest expression of MT receptor mRNA was detected in the corpus luteum collected on day 23 of gestation, which was significantly higher than that of all other tissues obtained from animals on day 23 of gestation, including the gravid myometrium $(P=0.034)$.

There was a significant (one-way ANOVA, $P<0.001$ ) increase in uterine $M T$ receptor mRNA expression in the later stages of gestation (Fig. 5a). Myometrial MT receptor
mRNA concentrations were significantly $(P=0.016)$ upregulated in the gravid uterus on day 20 of gestation, and remained relatively high until the day of expected birth. Differences in MT receptor gene expression between the gravid and non-gravid uteri were observed on days 23-26 of gestation, with higher MT receptor mRNA concentrations detected in the gravid uterus. However these differences were not significant until days 25 and 26 $(P<0.009)$ of gestation. A significant $(P=0.003)$ downregulation in MT receptor mRNA expression occurred in the non-gravid uterus at term compared with the non-gravid uterus at day 22 of gestation. Only six stages of gestation were available for the Q-PCR analysis of MT receptor mRNA expression in the corpus luteum. Overall, there was no significant (one-way ANOVA, $P=0.516$ ) difference in luteal MT receptor mRNA expression across pregnancy stages (Fig. 5b). However, a direct comparison between days 23 and 26 of gestation showed a significant (independent $t$-test, $P=0.006$ ) decrease in MT receptor mRNA expression on the day of expected birth.

\section{MT receptor concentrations}

A comprehensive study examined myometrial MT receptor concentrations in gravid and non-gravid uteri collected from day 11 of gestation, through to the expected day of birth (day 26), and then in post-partum tissues. Protein concentrations $(\mu \mathrm{g} / \mathrm{ml}$ membrane preparation) did not change significantly during pregnancy, and the differences between uteri were negligible. Therefore, MT receptor concentrations were presented as $\mathrm{fmol} / \mathrm{mg}$ protein to determine receptor changes in myometrial tissues. In midpregnancy, days 11-20, MT receptor concentrations were 


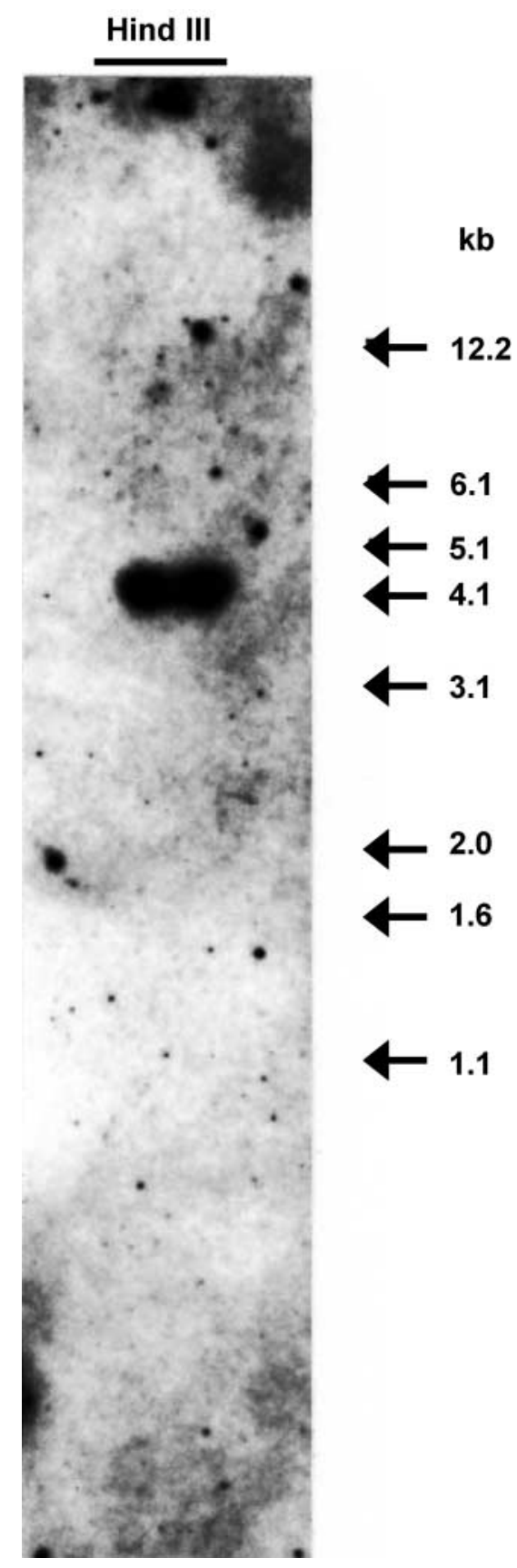

Figure 2 Hybridisation of tammar genomic DNA $(15 \mu \mathrm{g})$ with a 580 bp, digoxygenin-labelled, tammar-specific MT receptor cDNA probe. The genomic DNA was restricted with a single restriction enzyme (HindIII), with DNA marker fragments shown on the right in $\mathrm{kb}$.

$150-400 \mathrm{fmol} / \mathrm{mg}$ protein, with no significant difference observed between the gravid and non-gravid myometrium (Fig. 6). A significant $(P<0.05)$ upregulation of MT receptors in the gravid uterus was first observed on day 21 , compared with days 16-18 of gestation, with receptors remaining high in the gravid myometrium until birth. In contrast, MT receptor concentrations remained low in the non-gravid myometrium throughout pregnancy.
The downregulation of MT receptors in the non-gravid myometrium was significant $(P<0.05)$ on day 23 of gestation, compared with the non-gravid myometrium on day 22. It was not until day 22 of gestation that myometrial MT receptor concentrations were significantly (paired $t$ test, $P=0.029$ ) higher in the gravid than in the non-gravid myometrium. There was also a significant difference in MT receptors between uteri on both days 23 and 26 $(P<0.01)$ of gestation (Fig. 6). On the day after birth (days $0-1$ post-partum), MT receptor concentrations were significantly $(P=0.01)$ decreased in the post-partum myometrium when compared with the gravid uterus on day 26 of gestation. Receptor concentrations also remained low in the non-post-partum myometrium. There was no difference in MT receptor expression between uteri up to 1 week after birth.

\section{Characterisation of corpus luteum MT receptors}

The specificity of ${ }^{125} \mathrm{I}$-OTA binding in the corpus luteum of pregnant animals was assessed in competitive displacement experiments using different OT and AVP receptor agonists and antagonists (Fig. 7). These data show that AVT and MT bound with relatively high affinity to the ${ }^{125} \mathrm{I}-$ OTA binding site, as did OT. In contrast, the two AVP receptor agonists LVP and PP had much lower binding affinities, as higher molar concentrations were needed to displace the ${ }^{125}$ I-OTA from the binding site. In general, the ligand affinities for the ${ }^{125}$ I-OTA binding site in the corpus luteum were in the following order of decreasing affinity: $\mathrm{AVT}=\mathrm{MT}>\mathrm{OT}>\mathrm{LVP} \gg \mathrm{PP}$ and indicate binding to an OT-like receptor, as in previous results in the myometrium (Siebel et al. 2002b). At the one stage of gestation examined (day 25), luteal MT receptor concentrations were $140-435 \mathrm{fmol} / \mathrm{mg}$ protein $(n=2)$. Insufficient tissues were available to assess ovarian MT receptor concentrations throughout gestation.

\section{Localisation of MT binding sites in the tammar uterus}

MT binding sites were localised specifically to the myometrium in both the gravid (Fig. 8A) and non-gravid (Fig. 8D) uterus, with intense ${ }^{125}$ I-OTA labelling in the myometrial smooth muscle layer. No labelling was present in the endometrium, as confirmed by histological analysis (Fig. $8 \mathrm{C}$ and F). In the negative control, $2 \mu \mathrm{M}$ OTA displaced ${ }^{125} \mathrm{I}$-OTA binding in the tammar uterus (Fig. 8B and $\mathrm{E})$.

\section{Discussion}

This study reported a partial $834 \mathrm{bp}$ sequence of the tammar MT receptor cDNA. The derived sequence of 278 amino acids comprises six of the seven transmembrane domains and starts approximately 33 amino acid residues into the amino-terminus. Further comparisons with OT receptor sequences from eutherian species have highlighted several regions of highly conserved amino acids 


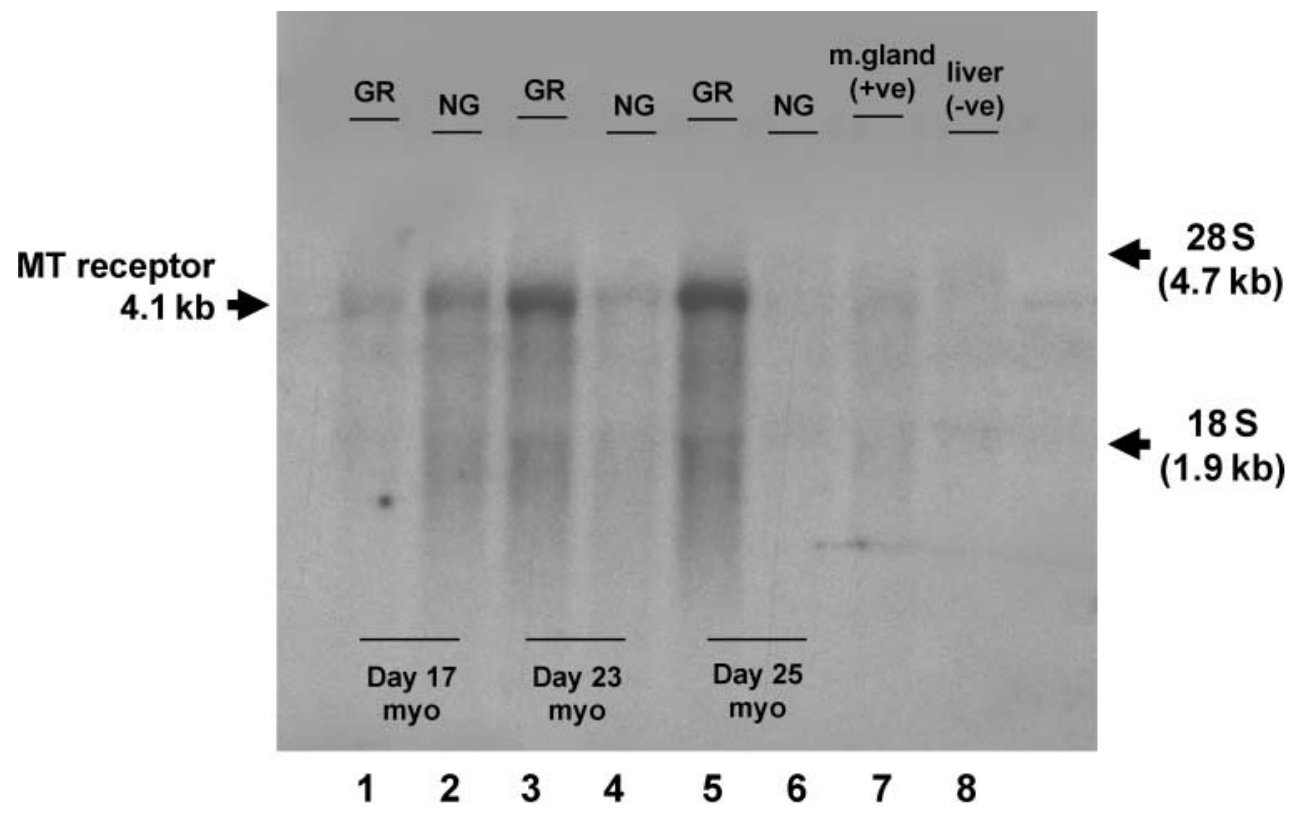

Figure 3 Northern hybridisation using a specific tammar MT receptor $\mathrm{CDNA}$ probe and total RNA $(20 \mu \mathrm{g})$ from gravid (GR) and non-gravid (NG) myometrium (myo) on days 17, 23 and 25 of gestation, with mammary gland ( $\mathrm{m}$. gland) and liver as a negative control. The approximate sizes of the $28 \mathrm{~S}$ and $18 \mathrm{~S}$ RNA, and the tammar MT receptor transcript $(4.1 \mathrm{~kb})$ are indicated.

in the OT/MT receptor that may be important for its biological action. Of particular interest are the highly conserved regions in transmembrane domains II, III and VI. This class of G-protein-coupled receptors typically binds ligand within the transmembrane domains, confirming their importance for ligand binding and selectivity (Kimura \& Ivell 1999). The transmembrane domains may also influence the ligand selectivity of signal transduction of the OT receptor (Chini et al. 1996). Experiments introducing point mutations into selected transmembrane domains have confirmed that there are different contact sites within the receptor molecule for the ligand and ligand-specific antagonists (Yarwood et al. 1997). Many of the key amino acids shown by mutagenesis to be important in ligand binding appear to be present in the tammar MT receptor sequence.



Figure 4 Mean \pm S.E.M. MT receptor mRNA concentrations in reproductive tissues from day-23 pregnant females $(n=4)$. a, significantly $(P<0.05)$ higher than all tissues; $b$, significantly $(P<0.05)$ higher than all tissues, except corpora lutea (CL). gr myo: gravid myometrium; ng myo: non-gravid myometrium; gr endo: gravid endometrium; $m$ vag: median vagina; YSM: yolk sac membrane. (a)

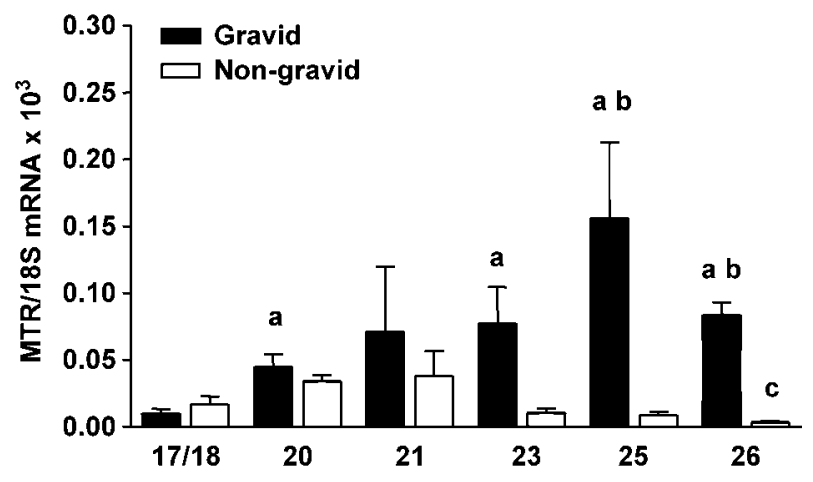

(b)

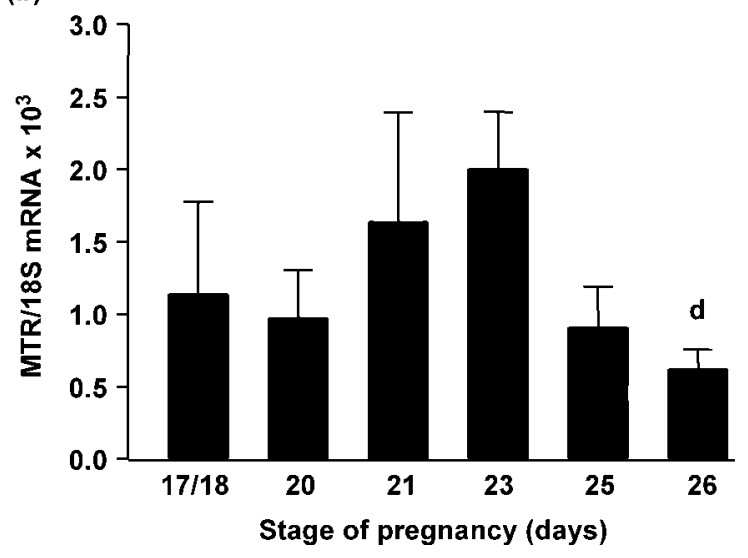

Figure 5 Mean \pm S.E.M. MT receptor mRNA concentrations in the (a) myometrium of the gravid and non-gravid uterus and (b) corpora lutea from day 17 of gestation to the day of birth (day 26; $n=4$ at each stage). a, $P<0.05$ higher than the gravid myometrium on days $17-18 ; b, P<0.05$ higher than the non-gravid uterus; $c, P<0.05$ lower than day-22 non-gravid myometrium; d, $P<0.05$ lower than day-23 corpora lutea. 


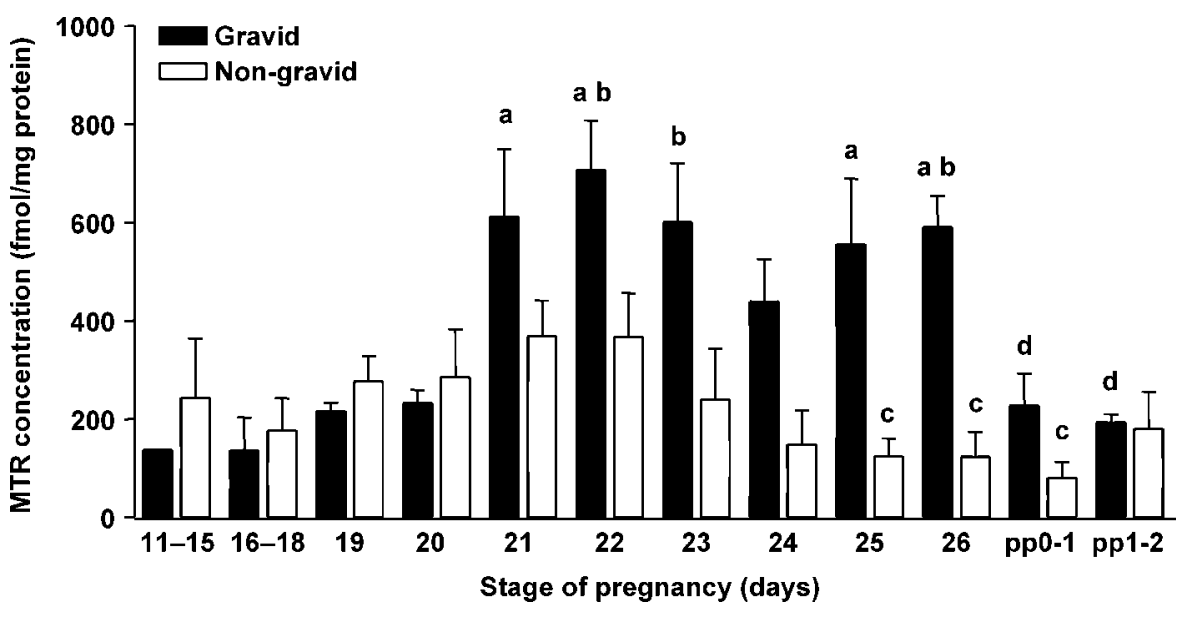

Figure 6 Mesotocin receptor concentrations in the myometrium of the gravid and non-gravid uterus from day 11 of gestation to 2 days post-partum (pp). Data are mean \pm S.E.M. (fmol/mg protein, $n=2-4$ at each stage). a, significantly $(P<0.05)$ higher than gravid myometrium on days 16-18 of gestation; b, significantly $(P<0.05)$ higher than non-gravid uterus; $c$, significantly $(P<0.05)$ lower than day-22 non-gravid myometrium; d, significantly $(P<0.05)$ lower than day-26 gravid myometrium.
Northern analysis confirmed the expression of a single MT receptor transcript of approximately $4.1 \mathrm{~kb}$ in both the myometrium and mammary gland of the tammar wallaby. In the human, there are two distinct OT receptor transcripts, approximately $3.6 \mathrm{~kb}$ in the mammary gland and $4.4 \mathrm{~kb}$ in ovary, uterine endometrium and myometrium (Kimura et al. 1992). In the rat, the OT receptor gene is highly expressed in the uterus and gives rise to three separate polyadenylation variants, with the predominant transcript detected at $6.5 \mathrm{~kb}$ (Rozen et al. 1995). Two major transcripts were identified in the bovine myometrium and endometrium at $2.0 \mathrm{~kb}$ and $6.5 \mathrm{~kb}$, with a third minor band at $3.5 \mathrm{~kb}$ (Bathgate et al. 1995). Usually, these variants differ in the length of the $3^{\prime}$-UTR, due to different polyadenylation sites. However in the tammar, there were no apparent polyadenylation variants of the MT receptor gene after exposure of the blot to film for up to 3 days.

Q-PCR demonstrated high expression of MT receptors in the uterus and ovary of the tammar wallaby. As in previous RT-PCR results, MT receptor mRNA expression in the median vagina and placenta of the tammar was almost undetectable. Supposedly, then, the median vagina does

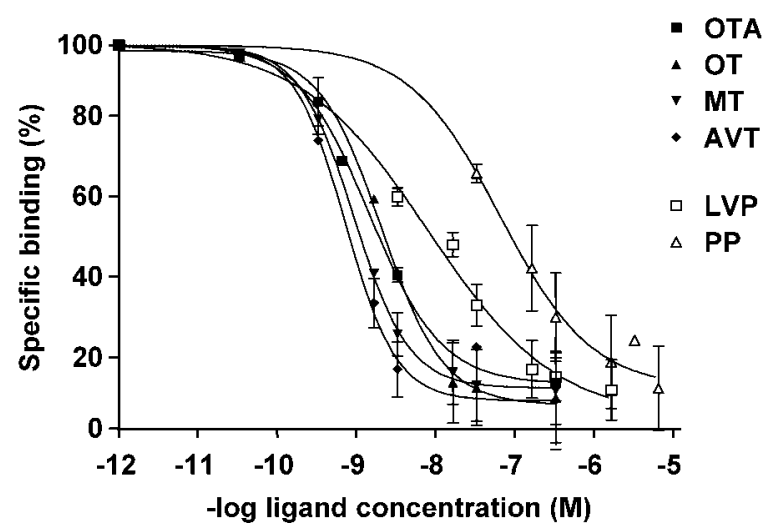

Figure 7 Competitive displacement of ${ }^{125} \mathrm{I}$-OTA binding in the corpus luteum on day 25 of gestation in the tammar wallaby by $\mathrm{d}\left(\mathrm{CH}_{2}\right)_{5}$ $\left[\operatorname{Tyr}(\mathrm{Me})^{2}, \mathrm{Tyr}^{4}, \mathrm{Orn}^{8}, \mathrm{Tyr}-\mathrm{NH}_{2}^{9}\right]$-vasotocin (OTA), mesotocin (MT), oxytocin (OT), arginine [Arg-8]-vasotocin (AVT), lysine [Lys-8]-vasopressin (LVP) and $\left[\mathrm{Phe}^{2}\right]$-vasopressin (PP). not respond to MT in the tammar. This is in contrast to the brushtail possum, where MT receptors are present in both the uterus and median vaginal sacs, implying that these tissues respond to MT as a single contractile unit (Sernia et al. 1991). The highest expression of the MT receptor transcript was detected in the tammar myometrium 4-5 days before birth and, for the first time, in the corpus luteum of pregnancy. In the cow, OT receptor gene transcripts are detected in most uterine tissues, with the highest levels of expression in the endometrium and myometrium at term. However, no OT receptor gene transcripts have been detected in the corpus luteum at any stage of pregnancy (Ivell et al. 1995). Similarly, the rodent myometrium is abundant in OT receptor mRNA during pregnancy (Larcher et al. 1995), but there are no OT receptors in the corpus luteum.

The radioreceptor assay data in this study demonstrated significant increases in MT receptor concentrations in the gravid myometrium as early as day 21 of gestation. Differences between the uteri occurred on days 22 and 23 of gestation, as well as on the day of birth. However, receptor concentrations do not precisely parallel MT receptor mRNA expression. Although there was a marked gravid uterus-specific increase in MT receptor mRNA concentrations on day 20 of gestation, differences in MT receptor mRNA expression between uteri were not significant until day 25 of gestation. This appeared to be due to a large variation in MT receptor mRNA concentrations in the gravid myometrium. In support of previous findings, there is a significant downregulation in both MT receptor mRNA and receptor concentrations in the non-gravid myometrium on day 25 of gestation (Parry et al. 1997). The upregulation of MT receptors in the gravid myometrium relates to the differential uterine responsiveness to exogenous MT between the gravid and non-gravid myometrium in late pregnancy (Parry et al. 1997). An increase in MT receptors in the gravid myometrium at the end of pregnancy is consistent with the idea that MT stimulates uterine contractions at birth. This stimulatory effect appears to be essential for normal parturition, as infusion 



Figure 8 Autoradiography localisation of MT binding sites in the tammar wallaby uterus on day 23 of gestation. Gravid uterus incubated with (A) ${ }^{125}$ I-OTA, (B) non-specific binding (NSB) with unlabelled OTA $(2 \mu \mathrm{M}),(\mathrm{C})$ histology of boxed section stained with H\&E. Nongravid uterus incubated with (D) ${ }^{125} \mathrm{I}-$ OTA, (E) NSB with unlabelled OTA, (F) histology of boxed section. Myo: myometrium; Lu: uterine lumen; EG: endometrial gland; c: capillary. Magnification $-\mathrm{A}, \mathrm{B}$, $\mathrm{D}$ and $\mathrm{E}: \times 20 ; \mathrm{C}$ and $\mathrm{F}: \times 80$. of an OT receptor antagonist in late-pregnant tammars delays birth (Renfree et al. 1996), and an increase in plasma MT is observed only during delivery (Parry et al. 1996). Therefore, evidence suggests that MT is an important part of the hormonal cascade associated with delivery in this species.

For further characterisation of uterine MT receptor expression in the tammar, specific MT binding sites were localised to the myometrium of both the gravid and nongravid uterus. Previous studies in sheep also reported specific OT binding to smooth muscle cells of the myometrium, as well as endometrial tissue and the oviduct with

${ }^{125}$ I-OTA (Ayad et al. 1991). Overall, the autoradiography studies in the tammar support the MT receptor assay and gene expression data, which demonstrated higher MT receptor concentrations in the gravid myometrium than in the non-gravid myometrium and endometrium during late pregnancy.

In the present study, relative MT receptor mRNA expression was highest in the corpus luteum, even when compared with the gravid myometrium. However, it is not clear whether this is due to an increase in the number of cells expressing MT receptor mRNA or to an upregulation of $M T$ receptor mRNA expression within each cell (Ivell et al. 2001). Pharmacological studies demonstrated the presence of a single high-affinity OT-like receptor in the corpus luteum of the pregnant tammar wallaby. The affinity $\left(K_{\mathrm{a}}\right)$ of this receptor for ${ }^{125}$ I-OTA is similar to that of the MT receptor in the myometrium.

Functional OT receptors have been detected in bovine granulosa cells, suggesting that OT may play an autocrine role in follicular growth (Okuda et al. 1997). In contrast, there is significant OT gene expression in the bovine corpus luteum, but no OT receptors, following the onset of labour. A suggested paracrine role for OT has been investigated within the primate ovary with the localisation of OT and OT receptors in luteal tissue and ovarian remnants of the marmoset monkey (Einspanier et al. 1994, 1997). This was the first evidence of the potential involvement of OT in the induction of luteinisation in any eutherian species.

Early and mid-luteal phase corpora lutea of the brushtail possum contain MT peptide concentrations similar to that of OT in the non-ruminant corpus luteum (Sernia et al. 1994). The presence of immunoreactive MT in a substantial 
population of cells is reminiscent of the situation in the sheep, where OT expression is restricted to the large luteal cells (Rodgers et al. 1983). Early work found no MT or OT protein in extracts of corpora lutea from pregnant tammar wallabies (Curlewis et al. 1988). However, evidence of an MT gene transcript has been shown in the preovulatory follicle and corpus luteum (Parry et al. 2000). These studies confirm that the tammar ovary has the ability to synthesise MT and suggest that an ovarian OT physiology was present early in the evolution of mammals.

The mechanism of luteal regression in the tammar wallaby is unknown. Q-PCR analysis of corpora lutea collected from late-pregnant tammars confirmed that MT receptor mRNA expression remains relatively high throughout most of gestation. However, at term, there was a decrease in MT receptor mRNA expression coinciding with luteolysis. These data support the hypothesis that a fall in ovarian MT receptor expression may be required for luteal regression.

In conclusion, MT binding sites were localised to the myometrium of the uterus in the pregnant tammar wallaby. Uterine MT receptor mRNA and receptor concentrations increased significantly in the gravid myometrium only, at 4-5 days before birth. Luteal MT receptor mRNA expression was relatively high throughout pregnancy, with a significant decrease observed on the expected day of birth. It therefore appears that MT receptor expression in the uterus and ovary of the tammar wallaby is under differential regulation, with the feto-placental unit having a major influence on myometrial MT receptors.

\section{Acknowledgements}

We acknowledge the Loxton Bequest (Faculty of Science, University of Melbourne) for providing funding to A L S during the preparation of this paper. We thank Peter Frappell (Department of Zoology, La Trobe University) for providing facilities to house the wallabies, Richard Ivell (University of Adelaide, formerly of the Institute for Hormone and Fertility Research, Hamburg) and Geoff Tregear (Howard Florey Institute) for the laboratory facilities to conduct the research. We are also most grateful to Maurice Manning for his kind gifts of the OTA and VP-like peptides, Helen Gehring for her assistance in the laboratory and with animal handling, and Peter Davis for catching the wallabies on Kangaroo Island.

\section{References}

Ayad VJ, Guldenaar SEF \& Wathes DC 1991 Characterization and localization of oxytocin receptors in the uterus and oviduct of the non-pregnant ewe using an iodinated receptor antagonist. Journal of Endocrinology 128 187-195.

Bathgate RAD, Rust W, Balvers M, Hartung S, Morley S \& Ivell R 1995 Structure and expression of the bovine oxytocin receptor gene. DNA and Cell Biology 14 1037-1048.

Chini B, Mouillac B, Balestre MN, Trumpp-Kallmeyer S, Hoflack J, Hibert M, Andriolo M, Pupier S, Jard S \& Barberis C 1996 Two aromatic residues regulate the response of the human oxytocin receptor to the partial agonist arginine vasopressin. FEBS Letters $397201-206$.
Curlewis JD, Renfree MB, Sheldrick EL \& Flint AP 1988 Mesotocin and luteal function in macropodid marsupials. Journal of Endocrinology 117 367-372.

Einspanier A, Ivell R, Rune G \& Hodges JK 1994 Oxytocin gene expression and oxytocin immunoactivity in the ovary of the common marmoset monkey (Callithrix jacchus). Biology of Reproduction 50 1216-1222.

Einspanier A, Jurdzinski A \& Hodges JK 1997 A local oxytocin system is part of the luteinization process in the preovulatory follicle of the marmoset monkey (Callithrix jacchus). Biology of Reproduction 57 16-26.

Gorbulev V, Buchner H, Akhundova A \& Fahrenholz F 1993 Molecular cloning and functional characterization of V2 [8-lysine] vasopressin and oxytocin receptors from a pig kidney cell line. European Journal of Biochemistry 215 1-7.

Ivell R, Rust W, Einspanier A, Hartung S, Fields M \& Fuchs AR 1995 Oxytocin and oxytocin receptor gene expression in the reproductive tract of the pregnant cow: rescue of luteal oxytocin production at term. Biology of Reproduction 53 553-560.

Ivell R, Kimura T, Muller D, Augustin K, Abend N, Bathgate RAD, Telgmann R, Balvers M, Tillmann G \& Fuchs AR 2001 The structure and regulation of the oxytocin receptor. Experimental Physiology 86 289-296.

Kimura T \& Ivell R 1999 The oxytocin receptor. Results and Problems in Cell Differentiation 26 135-168.

Kimura T, Tanizawa O, Mori K, Brownstein M \& Okayama H 1992 Structure and expression of a human oxytocin receptor. Nature $356526-529$.

Kubota Y, Kimura T, Hashimoto K, Tokugawa Y, Nobunaga K, Azuma C, Saji F \& Murata E 1996 Structure and expression of the mouse oxytocin receptor gene. Molecular and Cellular Endocrinology 124 $25-32$.

Larcher A, Neculcea J, Breton C, Arslan A, Rozen F, Russo C \& Zingg HH 1995 Oxytocin receptor gene expression in the rat uterus during pregnancy and the oestrous cycle and in response to gonadal steroid treatment. Endocrinology 136 5350-5356.

Munson P \& Rodbard D 1980 LIGAND: a versatile computerized approach for the characterization of ligand-binding systems. Analytical Biochemistry 107 220-228.

Okuda K, Uenoyama Y, Fujita Y, Iga K, Sakamoto K \& Kimura T 1997 Functional oxytocin receptors in bovine granulosa cells. Biology of Reproduction 56 625-631.

Parry LJ \& Bathgate RAD 1998 Mesotocin receptor gene and protein expression in the prostate gland, but not testis, of the tammar wallaby, Macropus eugenii. Biology of Reproduction 59 1101-1107.

Parry LJ, Guymer FJ, Fletcher TP \& Renfree MB 1996 Release of an oxytocic peptide at parturition in the marsupial, Macropus eugenii. Journal of Reproduction and Fertility 107 191-198.

Parry LJ, Bathgate RAD, Shaw G, Renfree MB \& Ivell R 1997 Evidence for a local fetal influence on myometrial oxytocin receptors during pregnancy in the tammar wallaby (Macropus eugenii). Biology of Reproduction 56 200-207.

Parry LJ, Bathgate RAD \& Ivell R 2000 Mammalian mesotocin: cDNA sequence and expression of an oxytocin-like gene in a macropodid marsupial, the tammar wallaby. General and Comparative Endocrinology 118 187-199.

Renfree MB, Parry LJ \& Shaw G 1996 Infusion with an oxytocin receptor antagonist delays parturition in a marsupial. Journal of Reproduction and Fertility 108 131-137.

Riley PR, Flint AP, Abayasekara DR \& Stewart HJ 1995 Structure and expression of an ovine endometrial oxytocin receptor cDNA. Journal of Molecular Endocrinology 15 195-202.

Rodgers RJ, O'Shea JD, Findlay JK, Flint AP \& Sheldrick EL 1983 Large luteal cells are the source of luteal oxytocin in the sheep. Endocrinology 113 2302-2304.

Rozen F, Russo C, Banville D \& Zingg HH 1995 Structure, characterization, and expression of the rat oxytocin receptor gene. PNAS 92 200-204. 
Salvatore C, Woyden C, Guidotti M, Pettibone D \& Jacobson M 1998 Cloning and expression of the rhesus monkey oxytocin receptor. Journal of Receptor and Signal Transduction Research 18 $15-24$.

Sebastian LT, De Matteo L, Shaw G \& Renfree MB 1998 Mesotocin receptors during pregnancy, parturition and lactation in the tammar wallaby. Animal Reproduction Science 51 57-74.

Sernia C, Garcia-Aragon J, Thomas WG \& Gemmell RT 1990 Uterine oxytocin receptors in an Australian marsupial, the brushtail possum, Trichosurus vulpecula. Comparative Biochemistry and Physiology A - Physiology 95 135-138.

Sernia C, Thomas WG \& Gemmell RT 1991 Oxytocin receptors in the mammary gland and reproductive tract of a marsupial, the brushtail possum (Trichosurus vulpecula). Biology of Reproduction 45 673-679.

Sernia C, Bathgate RAD \& Gemmell RT 1994 Mesotocin and arginine-vasopressin in the corpus luteum of an Australian marsupial, the brushtail possum (Trichosurus vulpecula). General and Comparative Endocrinology 93 197-204.
Siebel AL, Gehring HM, Nave CD, Bathgate RAD, Borchers CE \& Parry LJ 2002a Up-regulation of mesotocin receptors in the tammar wallaby myometrium is pregnancy-specific and independent of estrogen. Biology of Reproduction 66 1237-1243.

Siebel AL, Gehring HM \& Parry LJ 2002 $b$ Effects of fetectomy on oxytocin receptors in the myometrium of the tammar wallaby. Biology of Reproduction 67 1242-1249.

Tyndale-Biscoe CH \& Renfree MB 1987 In Reproductive Physiology of Marsupials, Cambridge: Cambridge University Press.

Yarwood NJ, Howl J \& Wheatley M 1997 Characterization of the human oxytocin receptor ligand binding site. Biochemical Society Transactions 25 436S.

Received 21 September 2004

First decision 12 November 2004

Accepted 13 December 2004 